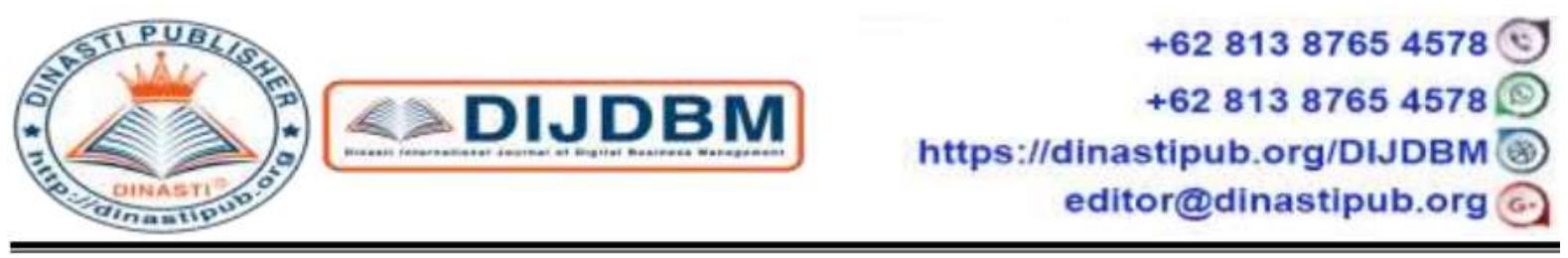

\title{
EFFECT OF WORK ENVIRONMENT AND MOTIVATION ON WORKLOAD AND ITS IMPLICATIONS ON EMPLOYEE PERFORMANCE PT. PLN (PERSERO) UP3 KEBON JERUK
}

Sahat Parulian ${ }^{1}$, Ahmad Hidayat Sutawijaya ${ }^{2}$

1) Magister of Management, Lecturer of Postgraduate, Mercu Buana University, Indonesia

${ }^{2)}$ Magister of Management, Lecturer of Postgraduate, Mercu Buana University, Indonesia

ARTICLE INFORMATION
Received: 25 January 2020
Revised: 30 January 2020
Issued: 9 February 2020
(filled in by Editor)
Corresponding author: first author
E-mail:
sahatparulian_25@ yahoo.com
a.h.sutawijaya@mercubuana.ac.id

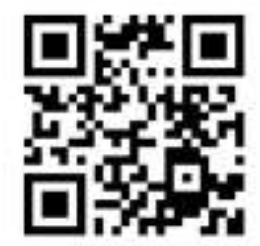

DOI:10.31933/DIJDBM
Abstract: This study aims to determine and clarify the effect of work environment and work motivation for workload and its implementation on employee performance. Respondents 67 employees (entire population). Data collection is done through interviews and questionnaires. Data were analyzed using path analysis (SmartPls 3.0 software) and correlation matrix between dimensions (SmartPls 3.0 software). The results showed that: (1) Work Environment and Motivation both partially and simultaneously affect Employee Performance; (2) Work environment, motivation and workload both partially and simultaneously affect employee performance; (3) Workload mediates the work environment and motivation on performance. Based on the analysis of the correlation matrix between dimensions, to improve the Work Environment, which has a positive correlation with Workload, it is recommended to maintain and improve the dimensions of Non-Physical Work Environment and also for employee performance also to improve the Physical Environment dimension. To increase motivation, which has a positive correlation with workload, it is recommended to maintain and improve hygiene. And for employee performance that is increasing the dimensions of intrinsic appreciation. To increase the workload that has a positive correlation with employee performance it is advisable to maintain and improve the dimensions of frustration

Keywords: Employee Performance, Workload, Motivation, and Work Environment 


\section{INTRODUCTION}

PLN as a BUMN in the electricity sector that runs the 35,000 MW electricity program and the completion of the 7,000 MW program continues to run and continues to roll. Even at the end of 2018 the achievement of the addition of power plants, transmissions and substations was quite significant. From the World Bank's Ease of Doing Business (EoDB) survey related to "Ease of Getting Electricity" Indonesia's ranking among the 190 countries surveyed has improved to 38 in 2018 compared to the previous year which was ranked 49th. This proves a positive contribution in improving the investment climate in Indonesia. Indonesia's electrification ratio in 2018 currently reaches $96.50 \%$, while the ratio of electrified villages is $95.93 \%$. The government has assigned PLN to increase the electrification ratio and electrify villages that are not yet electrified, including disadvantaged, frontier and outermost regions.

There are many factors that affect performance, there are three biggest factors, namely work environment, motivation and workload. These results indicate that it is estimated that the factors affecting the decline in the performance of employees of PT PLN (Persero) Kebon Jeruk Customer Service Implementation Unit. Of the three factors obtained by the author conducted a pre-survey of the alleged causes of low employee performance from work environment factors, motivation and workload.

Performance is generally defined as the success or success of someone in carrying out a job. Employee performance is the result of work achieved by someone in carrying out the tasks assigned to him. Performance includes the quality and quantity of output and reliability at work. Employees can work well if they have high performance so that they produce good work too. High performance owned by employees is expected to achieve organizational goals. Other problems encountered in employee performance can be seen from several factors such as internal factors and external factors. Factors that are thought to reduce performance in organizations include the work environment, motivation and workload according to preresearch data.

\section{LITERATURE REVIEW}

\section{A. Work Environment}

According to Nitisemito in Hamid and Rismawati (2017: 86) in defining the work environment is everything that is around workers that can influence themselves in carrying out embedded tasks. According Sedarmayanti (2011:21) defines the work environment is the overall tools and materials faced by the surrounding environment in which a person works, work methods, as well as working knowledge both as individuals and as groups. The work environment is focused on the physical work environment. The physical work environment is all physical forms that are around the workplace that can affect employees directly or indirectly.

Sedarmayanti in Suminar et. al (2015), also states that in outline, the dimensions of the work environment are divided into two, namely:

1) Physical work environment

All physical conditions are found around the workplace which can affect employees directly or indirectly. The physical work environment itself can be divided into two categories, namely:

a) Environment related to employees, such as work centers, chairs, tables, and so on.

b) An intermediate or general environment can also be called a work environment that affects the human condition, for example temperature, humidity, air circulation, lighting, noise, mechanical vibrations, unpleasant odors, colors, and others. 
2) Non-physical work environment

All circumstances that occur relating to physical relations, both with superiors and with fellow colleagues, or with subordinates. Non-physical work environments are also a group of work environments that cannot be ignored.

\section{B. Motivation}

According to Armstrong's (2014: 170) expressed his opinion about motivation as follows: "Motivation is the strength and direction of behavior and the factors that influence people to behave in certain ways. People are motivated when they hope that action may lead to the achievement of goals and rewards that are valued - that satisfy their needs and desires".

According to Robbins \& Judge (2013: 212-213), explains that there are several reasons for setting goals that can increase an individual's work motivation:

1) Challenging goals or targets attract the attention of the individuals concerned so as to make them more focused

2) A goal or target that is difficult to provide energy because the individual must strive harder to achieve it. For example, when facing a difficult exam, it will make individuals study harder than when told about easy exams.

3) When the goal is difficult to achieve, individuals will persevere to try to achieve that goal.

4) Difficult goals or targets make the individual concerned try to find ideas or strategies to be able to carry out tasks or jobs more effectively.

\section{Workload}

Permendagri No. 12 of 2008 concerning Guidelines for Workload Analysis within the Ministry of Home Affairs and Local Governments states that workload is the amount of work that must be borne by an office / organizational unit and is the product of work volume and time norms. If the ability of workers is higher than the demands of the job, boredom will emerge. But on the contrary, if the worker's ability is lower than the demands of the job, more fatigue will emerge.

According to Koesomowidojo (2017: 21) explains that workload analysis is the process of determining the number of hours worked human resources who work, use, and are needed in completing a job for a certain period of time. According to Astianto and Suprihhadi (2014) in Syamsu (2019) states that employee workload can occur in three conditions. First, the workload is according to standards. Second, the workload is too high (over capacity). Third, the workload that is too low (under capacity) The excessive workload given to employees will reduce employee performance.

According to Tarwaka (2015: 131) explains that the method using subjective workload measurement techniques (Subjective Workload Assessment Technique - SWAT) consists of three dimensions of load size associated with performance, namely:

1) Time load shows the amount of time available in planning, implementing and monitoring tasks;

2) Mental effort load (mental effort load), which means the amount of mental effort in carrying out a job;

3) psychological stress load which shows the level of work risk, confusion, and frustration. 


\section{Employee Performance}

Understanding of performance according to Handoko (1987) in Priyono (2010: 187) states that job appraisal is the process through which organizations evaluate or assess employee work performance. job appraisal is a stage carried out to make an assessment of the work of employees

Employee performance appraisal provides many benefits, both for the company and the employees themselves. According to Kasmir (2016: 189) Performance appraisal is a function of human resource management, so it should be run as well as possible.

According to Mangkunegara (2017: 67) factors that affect performance (job performance) are:

\section{1) Ability factor}

Psychologically, employees' abilities consist of potential abilities (IQ) and reality abilities (knowledge $\mathrm{x}$ skills). This means that an employee who has an IQ above average (IQ 110-120) with adequate education for his position and skilled in doing daily work, then he will more easily achieve the expected performance. Therefore, employees need to be placed in jobs that match their expertise.

\section{2) Motivation factor}

Motivation is formed from the attitude of an employee in dealing with work situations. Motivation is a condition that drives employees who are directed to achieve organizational goals (work goals). Mental attitude is a mental condition that drives employees to try to achieve maximum work performance. Mental attitude of employees must be mental attitude that is psychophysical (mentally, physically, goals, and situations), meaning that an employee must be prepared mentally, physically able, understand physically, understand the main objectives of the work targets to be achieved, able to take advantage of , and create a work situation.

\section{E. Theoretical Framework}

Based on the theoretical study above, it can be indicated that there is a relationship between the work environment and workload. According to Ihsan et.al (2015) has examined the relationship between the work environment and workload that is the measurement results associated with measurement data noise and temperature of the work environment and workload of each work line. From the results of the study according to Pranaputra et.al (2019) explains that workload has a positive and significant effect on work motivation, the more appropriate the workload with the ability of employees, the higher the work motivation of employees, and vice versa. The results of research conducted by Muhammad et.al (2016) which shows that there is a significant influence on employee performance. According to Sujana (2012: 19) the results of the study explained that motivation had a significant positive effect on performance. That is, the higher the motivation of employees, the higher the performance produced. Conversely the lower the motivation of employees, the lower the performance produced. According to Adityawarman et.al (2015) concluded from the research that the correlation of workload with performance shows that the highest correlation is between role demands with organizational variables and the lowest correlation is between work demands with organizational variables. Assumptions are the interrelationships between work environment variables and motivation together with workload. Based on the results of the research that has been stated above that each variable has a positive influence in influencing work motivation. Assumptions about the relationship between work environment variables, motivation and workload together on employee performance. Based on the results 
of the research that has been informed above, that each variable has a positive influence in influencing employee performance.

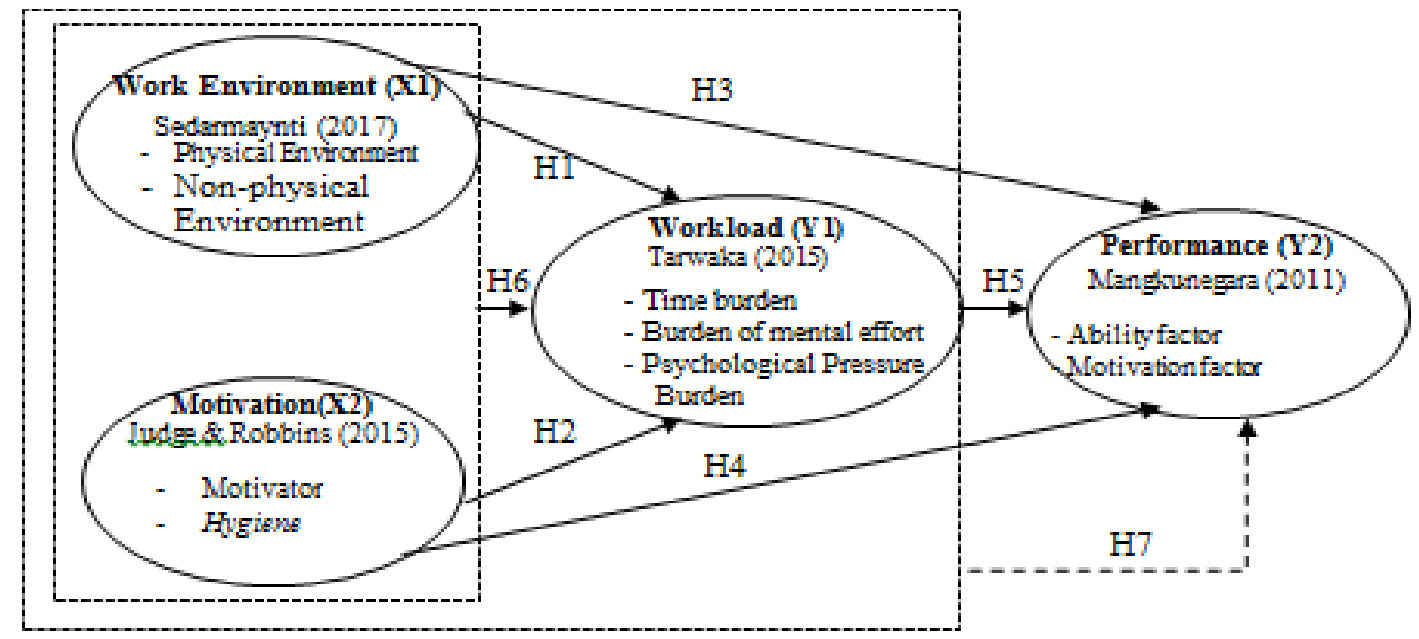

Fig 1:- Inter-Variable Relationship Model

\section{F. Hipotesis}

H1: The work environment has a significant effect on workload.

H2: Motivation has a significant effect on workload.

H3: The work environment has a significant effect on employee performance.

H4: Motivation has a significant effect on employee performance.

H5: Workload has a significant effect on employee performance.

H6: Work environment and motivation together have a significant effect on workload.

H7: Work environment, motivation and workload together have a significant effect on employee performance.

H8: Significant workload mediates the work environment and motivation on employee performance.

\section{RESEARCH METHODS}

This type of research will be used quantitative research using primary data in the form of pre-survey. To get complete data as a refinement of the study the author also uses secondary data in the form of report data related to the variables to be discussed namely, work environment, motivation on employee performance with workload as a mediating variable at PT. PLN (Persero) Kebon Jeruk Customer Service Unit (UP3).

\section{A. Population and Sample}

The Population in this study was determined and limited to employees of PT. PLN (Persero) Kebon Jeruk Customer Service Unit (UP3) totaling 67 (sixty seven) people based on employee data in December 2018 with permanent status.

\section{B. Method Analysis}

The method used as follows This study uses data analysis techniques using SmartPLS software version 3.2.7 which is run on computer media. PLS (Partial Least Square) is a structural equation analysis (Structural Equation Modeling) or abbreviated variant-based SEM that can simultaneously test measurement models as well as structural model testing. The measurement model is used to test the validity and reliability, while the structural model 
is used to test causality (hypothesis testing with predictive models). Furthermore, Ghozali (2006) explained that PLS is an analysis technique that is soft modeling because it does not assume the data must be of a certain scale measurement, which means the number of samples can be small (under 100 samples).

\section{FINDINGS AND DISCUSSION}

Based on the results of the study it can be seen that female employees numbered 15 people with a level of $22.39 \%$ while male sex numbered 52 people with a percentage level of $77.61 \%$. Most of the educational background of employees is high school, namely $41.79 \%$ percent of the total number of employees. This is motivated by the need for work that requires employees from the Vocational School in the field of electricity and machinery.

Descriptive statistical analysis of research variables is used to determine the tendency of the answers to the questionnaire or the extent to which respondents responded according to the choice of answer categories by using a Likert scale from scale 1 (strongly disagree) to 5 (strongly agree) to the statements of each variable. Based on the tabulated answers above, it can be seen that the Work Environment variable has an average of 3.05. that Motivation variable has an average of 3.12. Workload Variable has an average of 3.26. Employee Performance variable has an average value of 3.35.

Evaluation of convergent validity from the examination of Average variance extracted (AVE) illustrates the magnitude of variance or diversity of manifest variables that can be possessed by latent constructs, the greater the variance or diversity of variable manifests that can be contained by latent constructs, the greater the representation of variable manifests towards its latent construct.

Evaluation of convergent validity from the examination of Average Variance Extracted (AVE) can be seen from the value of AVE based on the results of data processing with Smart PLS version 3.0.

\begin{tabular}{lc}
\hline \multicolumn{1}{c}{ Variable } & Average Variance Extracted (AVE) \\
\hline Work Environment & 0.595 \\
Motivation & 0.574 \\
Workload & 0.572 \\
Performance & 0.718 \\
\hline
\end{tabular}

Table 1:- Average Variance Extracted (AVE) for Each Variable

For all variables having AVE values> 0.5, namely 0.595 for the work environment, 0.574 for motivation, 0.572 for workload and 0.718 for performance. Evaluation of convergent validity from internal consistency reliability checks can be seen from the Cronbach's Coefficient Alpha and Composite Reliability (CR) values shown in the following table 4.10. The table presented is the result of SmartPLS version 3.0 calculations

\begin{tabular}{lcc}
\hline \multicolumn{1}{c}{ Variabel } & Cronbach's Coefficient Alpha & Composite Reability (CR) \\
\hline Work Environment & 0.915 & 0.930 \\
\hline Motivation & 0.894 & 0.915 \\
\hline Workload & 0.906 & 0.923 \\
\hline The Performance & 0.934 & 0.947
\end{tabular}

Table 2:- Composite Reability (CR)

Cronbach's Coefficient Alpha value for the work environment, motivation, workload and performance variables is more than 0.6 or even close to 1 and the Composite reliability $(\mathrm{CR})$ value is more than 0.7 . 
It is known that the Cronbach's Coefficient Alpha value and the Composite reliability value for all research variables are more than 0.80 or even close to 1 . These values have exceeded the standard, respectively $>0.6$ and $>0.7$, so that all variables in the study are declared reliable.

\begin{tabular}{lccc}
\hline & $\begin{array}{c}\text { Original } \\
\text { Sample(O) }\end{array}$ & $\begin{array}{c}\text { T Statistic } \\
(\text { O/STDEV) }\end{array}$ & P Values \\
\hline Work Environment (x1) -> Workload (y1) & 0.307 & 0.113 & 0.007 \\
\hline Work Environment (x1) -> Performance (y2) & 0.276 & 0.115 & 0.017 \\
\hline Motivation (x2) -> Workload (y1) & 0.599 & 0.106 & 0.000 \\
\hline Motivation (x2) -> Performance (y2) & 0.249 & 0.099 & 0.012 \\
\hline Workload (y1) -> Performance (y2) & 0.442 & 0.112 & 0.000 \\
\hline
\end{tabular}

Fig 2 : Inner Model (Original Sample)

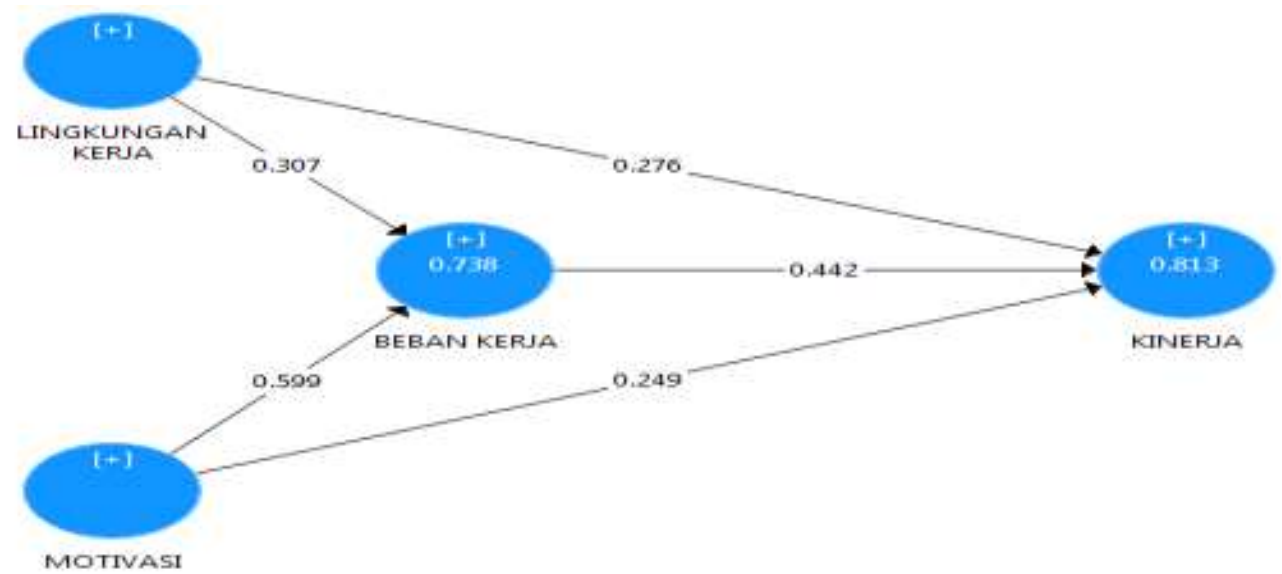

Fig 2 : Inner Model (Original Sample)

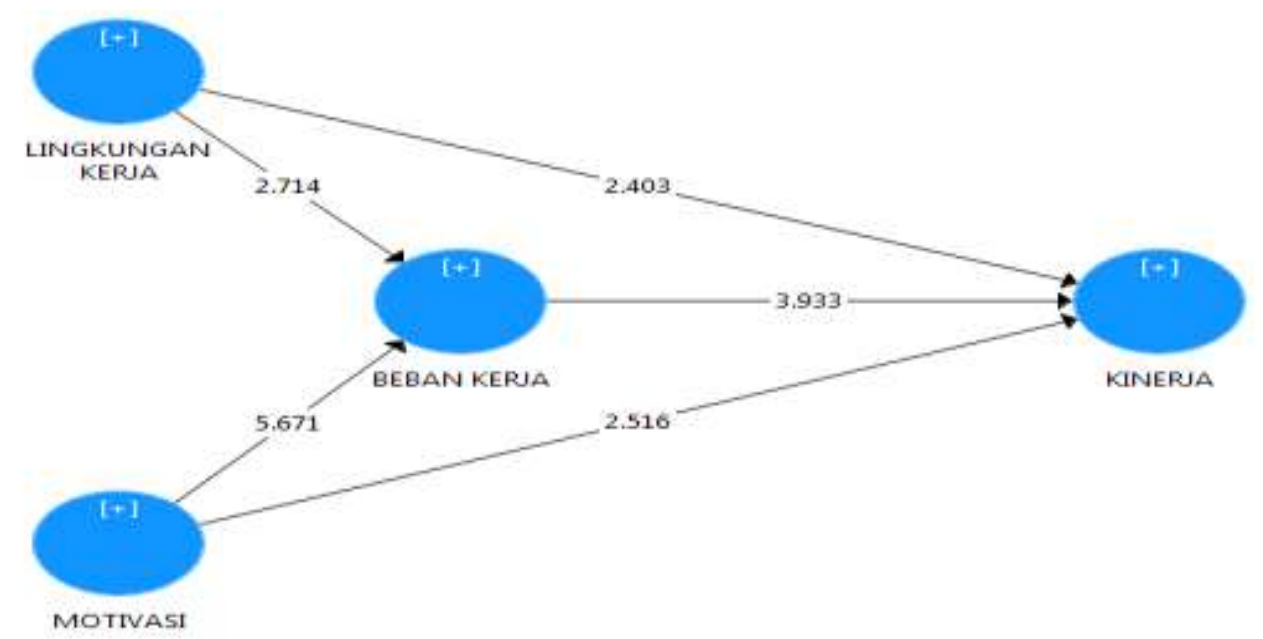

Fig 3 : Inner Model (T Statistik (O/STDEV))

To evaluate the R2 value based on the calculation using the SmartPLS version 3.0 algorithm, the R2 value is 0.738 for the workload variable and 0.813 for the Performance variable. The value of $\mathrm{R} 2$ indicates that the level of determination of exogenous variables 
(Work Environment and Motivation) towards the endogenous is quite high.. The simultaneous effect of Work Environment variables, Motivation on Workload can be done by calculating $\mathrm{f}$ arithmetic / $\mathrm{f}$ statistics using the formula as below.

$\mathrm{R} 2=0,738$ (Workload)

$\mathrm{F}_{\text {count }} 1=\frac{\frac{R^{2}}{(k-1)}}{1-R^{2} /(n-k)}$

$\mathrm{F}_{\text {count }} 1=\frac{\frac{0,738}{(4-1)}}{1-0,738 /(67-4)}$

$\mathrm{F}_{\text {count }} 1=0,246 / 0,00415$

$\mathrm{F}_{\text {count }} 1=59.277$

So the F count is 1 (Workload variable) which is 59,277

The simultaneous effect of Work Environment, Motivation and Workload variables on Performance can be done by calculating $\mathrm{f}$ arithmetic / $\mathrm{f}$ statistics using the formula as below.

$\mathrm{R}^{2}=0,813$ (Performance)

$\mathrm{F}_{\text {count }} 2=\frac{\frac{R^{2}}{(k-1)}}{1-R^{2} /(n-k)}$

$\mathrm{F}_{\text {count }} 2=\frac{\frac{0,813}{(4-1)}}{1-0,813 /(67-4)}$

F Performance $2=0,271 / 0.00296$

F Performance $2=91.554$

So the F count is 2 Performance variable) which is 91.554 .

The purpose of testing the Goodness of Fit Index $(\mathrm{GoF})$ is to validate the combined performance of the measurement model (outer model) and the structural model (inner model) obtained through calculations as follows:

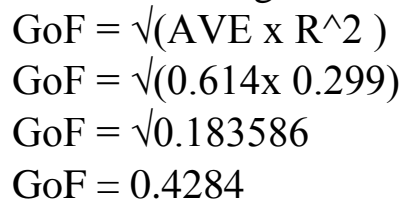

The purpose of testing Brelevance B (Q2) predictive test is to validate Model. BH2 calculation results are as follows:

$\mathrm{Q} 2=1-(1-\mathrm{R} 12)(1-\mathrm{R} 22)$

$\mathrm{Q} 2=1-(1-\mathrm{R} 12)(1-\mathrm{R} 22)$

$\mathrm{Q} 2=1-(1-0.738)(1-0.813)$

$\mathrm{Q} 2=1-(0.262)(0.187)$

$\mathrm{Q} 2=1-0.048994$

$\mathrm{Q} 2=0.951006$

Based on the predictive relevance (Q2) calculation above, the value is 0.951 . In this research model, endogenous latent variables have predictive relevance (Q2) values greater than 0 (zero) so that exogenous latent variables as explanatory variables are able to predict their endogenous variables namely performance or in other words prove that this model is considered to have good predictive relevance.

\begin{tabular}{lccc}
\hline Work Environment (x1) -> Workload (y1) & $\begin{array}{c}\text { T Statistic } \\
(\mathbf{O} / \text { STDEV) }\end{array}$ & $\begin{array}{c}\text { T Table } \\
0.307\end{array}$ & $\begin{array}{c}\text { P } \\
\text { Values }\end{array}$ \\
\hline Work Environment (x1) -> Performance (y2) & 0.276 & 1.668 & 0.007 \\
\hline
\end{tabular}




\begin{tabular}{|c|c|c|c|c|c|c|}
\hline \multicolumn{4}{|c|}{ Motivation (x2) -> Workload (y1) } & 0.599 & 1.668 & 0.000 \\
\hline \multicolumn{4}{|c|}{ Motivation (x2) -> Performance (y2) } & 0.249 & 1.668 & 0.012 \\
\hline \multicolumn{4}{|c|}{ Workload (y1) -> Performance (y2) } & 0.442 & 1.668 & 0.000 \\
\hline & $\begin{array}{c}\mathbf{R} \\
\text { square }\end{array}$ & $\begin{array}{c}\mathbf{F} \\
\text { Statistik }\end{array}$ & $\begin{array}{c}\mathbf{F} \\
\text { Tabel }\end{array}$ & Alpha & \multicolumn{2}{|c|}{ Conclusion } \\
\hline$(\mathrm{LK}, \mathrm{MOT})->\mathrm{BB}$ & 0.738 & 59.277 & 2.74 & 0.05 & \multicolumn{2}{|c|}{$\begin{array}{c}\text { Fcount }>\text { FTabel (H6 } \\
\text { received) }\end{array}$} \\
\hline $\begin{array}{c}\text { (LK, MOT, BB) -> } \\
\text { KIN }\end{array}$ & 0.813 & 91.554 & 2.74 & 0.05 & \multicolumn{2}{|c|}{$\begin{array}{c}\text { Fcount }>\text { F Tabel }(\mathrm{H7} \\
\text { received })\end{array}$} \\
\hline
\end{tabular}

Table 3:- Effect of Independent Variables on Dependent Variables

1. Hypothesis 1 - Work environment has a significant effect on workload. Obtained a path coefficient of 0.307 and $t$ arithmetic $(2,714)>t$ Table $(1,668)$ with $p$ of 0.007 , thus H1 is accepted ( $\mathrm{p}<0.05)$ and HO is rejected, the Work Environment has a significant positive effect on workload.

2. Hypothesis 2 - Motivation has a significant effect on workload. Obtained a path coefficient of 0.599 and $t$ arithmetic $(5,671)>t$ Table $(1,668)$ with p of 0,000 , thus H2 is accepted $(\mathrm{p}<0.05)$ and $\mathrm{H} 0$ is rejected, Motivation has a significant positive effect on Workload.

3. Hypothesis 3 - Work environment has a significant effect on performance.Obtained a path coefficient of 0.276 and $t$ arithmetic (2.403) > t Table (1.668) with p of 0.017 , thus H2 is accepted $(\mathrm{p}<0.05)$ and $\mathrm{HO}$ is rejected, the Work Environment has a significant positive effect on performance.

4. Hypothesis 4 - Motivation has a significant effect on performance. Obtained a path coefficient of 0.249 and $t$ arithmetic $(2,516)>t$ Table $(1,668)$ with $p$ of 0.012 , thus H2 is accepted $(\mathrm{p}<0.05)$ and $\mathrm{H} 0$ is rejected, motivation has a significant positive effect on performance.

5. Hypothesis 5 - Workload has a significant effect on performance. Obtained a path coefficient of 0.442 and $t$ arithmetic $(3,933)>t$ Table $(1,668)$ with $p$ of 0,000 , thus H2 is accepted $(\mathrm{p}<0.05)$ and $\mathrm{H} 0$ is rejected, Workload has a significant positive effect on performance.

6. Hypothesis 6 - Work Environment and Motivation have a significant effect on Workload. Work Environment and Motivation Variables have (R2) which is 0.738 with a statistical $\mathrm{f}$ value of 59.277 and the $\mathrm{f}$ table value at alpha 0.05 is 2.75 . This means that $\mathrm{f}$ arithmetic $(59,277)>\mathrm{f}$ Table $(2.74)$, then $\mathrm{H6}$ is accepted and H0 is rejected. Thus it can be concluded that hypothesis 6 is proven which states that the Work Environment and Motivation variables have a positive and significant influence on Workload.

7. Hypothesis 7 - Work environment, Motivation and Workload affect Performance. Motivation Work Environment Variable, and Workload has (R2) is 0.813 with a statistical $f$ value of 91.554 and an $f$ table value at alpha 0.05 is 2.74 . This means that $f$ arithmetic $(91,554)>\mathrm{f}$ Table $(2.74)$, then $\mathrm{H} 7$ is accepted and $\mathrm{H} 0$ is rejected. Thus it can be concluded that hypothesis 7 is proven which states that the variable Work Environment, Motivation and Workload has a positive and significant effect on performance. 
8. Hypothesis 8 - Workload mediates the Work Environment and Motivation on Performance. The path coefficient value of the direct influence of the work environment on performance $0.076>$ the value of the path coefficient of the indirect effect of the work environment on performance is 0.136 then the work environment on performance is not mediated by workload variables and the value of the path coefficient of the direct influence of motivation on performance 0.249> direct compensation for performance is 0.264 then motivation for performance is not mediated by workload variables.

\begin{tabular}{|c|c|c|c|c|c|c|}
\hline \multirow{2}{*}{ Variabel } & \multirow{2}{*}{ Dimension } & \multicolumn{3}{|c|}{ Job Satisfaction (Y1) } & \multicolumn{2}{|c|}{$\begin{array}{c}\text { Employee } \\
\text { Performance (Y2) }\end{array}$} \\
\hline & & Y1.1 & Y1.2 & Y1.3 & Y2.1 & Y2.2 \\
\hline \multirow{2}{*}{$\begin{array}{l}\text { Work Environment } \\
\text { (X1) }\end{array}$} & Environment Physical & 0.210 & 0.283 & -0.130 & 0.369 & 0.161 \\
\hline & $\begin{array}{c}\text { Non-Physical } \\
\text { Environment }\end{array}$ & -0.203 & 0.197 & 0.473 & 0.103 & 0.196 \\
\hline \multirow{2}{*}{$\begin{array}{l}\text { Motivation } \\
\quad(\mathrm{X} 2)\end{array}$} & Motivator & 0.203 & 0.181 & 0.127 & 0.047 & -0.054 \\
\hline & Hygiene & 0.598 & 0.248 & 0.375 & 0.448 & 0.604 \\
\hline
\end{tabular}

\begin{tabular}{cccc}
\hline \multirow{2}{*}{ Variabel } & \multirow{2}{*}{ Dimension } & \multicolumn{2}{c}{ Employee Performance (Y2) } \\
& Y2.1 & Y2.2 \\
\hline \multirow{3}{*}{ Workload (Y1) } & Time Burden & 0.171 & 0.115 \\
\cline { 2 - 4 } & Mental Operating Expenses & 0.533 & 0.424 \\
\cline { 2 - 4 } & Psychological Pressure Burden & 0.208 & 0.376 \\
\hline
\end{tabular}

Table 8:- Matrix Correlation Results among Dependent Variable Dimensions and Its Dependent Variable

1. In the Work Environment variable against Workload variable the highest correlation dimension is the Work Environment to the Non-Physical Environment dimension, amounting to 0.473 .

2. In the Work Environment variable to the highest correlation dimension Performance variable is the Work Environment to the Physical Environment dimension, amounting to 0.369 .

3. In the variable Motivation on the Workload variable the highest correlation dimension is Motivation on the Hygiene dimension, amounting to 0.598 .

4. On the variable Motivation on Performance variables the highest correlation dimension is Motivation on Hygiene dimensions, amounting to 0.604 .

5. In the variable Workload to the highest correlation dimension Performance variable is the Workload to the dimension of Mental Operating Expenses, amounting to 0.533.

\section{Discussion}

The results of this study indicate that the Work Environment and Motivation have a significant positive effect on Workload and Performance. If the Work Environment and Motivation are mediated by the Workload variable, the effect becomes very significant on Performance. In addition, workload also has a significant positive effect on performance.

\section{Effect of Work Environment on Workload (Hypothesis 1)}


The value of $\mathrm{p}$ value of the influence of the work environment variables on workload is significant with a $\mathrm{p}$ value of 0.007 , $\mathrm{T}$ statistic of 2.714 and the original sample is positive. Because the $\mathrm{p}$ value obtained is significant, $\mathrm{T}$ statistic $>1.668$ and the original sample is positive then Ho is rejected and it is concluded that the work environment has a positive and significant effect on workload if the work environment with employee capability, the higher the workload of employees, and vice versa.

Air temperature, air pressure, humidity, noise, lighting, all of which can be reflected in performance and also for work comfort caused by the work environment can also affect the attitudes and performance of workers. Information relating to the work environment is physiological, psychological and biological. A comfortable work environment will certainly affect the comfort of employees completing their work. However, if the work environment in this case is less than optimal lighting, room temperature and layout (decoration) that is hot and unstable, the noise due to other sounds will create inconvenience for employees so that the employees will do jobs that are not in accordance with established or nonstandard procedures resulting from unfavorable environmental conditions

\section{Effect of Motivation on Workload (Hypothesis 2)}

The $\mathrm{p}$ value of the influence of motivational variables on workload is significant with a $p$ value of 0,000 , T statistic of 5,565 and the original sample is positive. Because the $p$ value obtained is significant, $T$ statistic $>1.668$ and the original sample is positive then Ho is rejected and it is concluded that the severity of the workload received by the employees of PT. PLN UP3 Kebon Jeruk is greatly influenced by the motivation of the employees. The higher the motivation provided can give encouragement in completing the tasks that are charged.

In this regard, if the dimensions in the motivation variable consisting of motivators and hygiene can be managed properly within the company, it can promptly encourage employees to do their utmost possible in completing their duties, and they believe that with success in the organization the company achieves goals and various the target, then personal interests will be maintained as well. The dimension of motivation variable that has the biggest influence on workload is the hygiene dimension, this is a top priority in managing workload in the company.

Based on the description above it can be concluded that motivation has a positive and significant effect on workload, so in providing motivation from superiors to subordinates must be done well. Related to this, then if the motivation given has gone well it is expected to also result in a decline in employee performance in the company.

This result was also corroborated by previous researchers namely Pranaputra, Randy; M. Havidz Aima (2019) who also got results from variables that had a positive and significant effect on work motivation, the more appropriate the workload of the employee's ability, the higher the employee's work motivation.

\section{Effect of Work Environment on Performance (Hypothesis 3)}

The value of $\mathrm{p}$ value of the influence of work environment variables on performance is significant with a $\mathrm{p}$ value of 0.012 , $\mathrm{T}$ statistic of 2.253 and the original sample is positive. Because the $\mathrm{p}$ value obtained is significant, $\mathrm{T}$ statistic> 1.668 and the original sample is positive then Ho is rejected and it is concluded that if the work environment of PT. PLN UP3 Kebon Jeruk is getting better and more comfortable, so employee performance will improve. This condition occurs because the work environment is an impetus that moves a person to work carrying out the tasks that are charged and or perform certain actions. 
This result was also corroborated by previous researchers namely Muhammad (2016) who also got the results of the work environment variable having a significant effect on employee performance at the Regional Revenue Service of Manado and Surjosuseno (2015) which also got the results of testing the work environment a positive and significant effect on the performance of employees at the UD Factory Ada Plastic and Sutoyo (2016) get test results that prove the existence of a significant positive effect on the work environment on the performance of employees of the Regional Civil Service Agency of the South Coastal District.

\section{Effect of Motivation on Performance (Hypothesis 4)}

The value of $p$ value of the influence of motivation variables on performance is significant with a $\mathrm{p}$ value of 0.012 , $\mathrm{T}$ statistic of 2.522 and the original sample is positive. Because the $\mathrm{p}$ value obtained is significant, $\mathrm{T}$ statistic> 1.668 and the original sample is positive then Ho is rejected and it is concluded that if work motivation increases, it will affect employee performance.

Based on the results of the data obtained in the questionnaire showed that the decrease in work motivation experienced by employees of PT. PLN (Persero) UP3 Kebon Jeruk due to the willingness of employees to try to achieve work performance exceeding coworkers is still lacking due to lack of motivation on some employees to do something to achieve the achievements or goals of the organization. Motivator factors when there are at work can form a strong motivation to be able to produce good work, as for these factors namely, achievement, recognition, job characteristics and responsibilities. The presence of hygiene factors will not increase work motivation for employees, but in the absence of these factors will lead to dissatisfaction, as for these factors namely the conditions of work, company policies, relations between superiors and subordinates and technical coaching in carrying out work.

Based on these theoretical studies, it can be indicated that there is a relationship between motivation and employee performance. This is supported by the results of research conducted by Pramadita (2015: 1784), Sutoyo (2016: 195), and Sugiharjo (2018: 136), Pranaputra, Randy; M. Havidz Aima (2019:57) who get the results of motivational variables having a significant effect on employee performance.

\section{Effect of Workload on Performance (Hypothesis 5)}

The $\mathrm{p}$ value value influences the workload variable on significant performance with a $\mathrm{p}$ value of 0,000 , T statistic of 4,021 and the original sample is positive. Because the $\mathrm{p}$ value obtained is significant, $\mathrm{T}$ statistic> 1.668 and the original sample is positive then Ho is rejected and it is concluded that the assignment given to the employee is too heavy then the employee feels burdened with the task so that if the workload increases it will affect the decline in employee performance.

Related to this, if the dimensions in the workload variable consisting of time load, mental business burden and psychological stress burden can be managed properly within the company, it can improve employee performance. The dimensions of the workload variable that has the greatest influence on performance are the dimensions of mental workload, which is a top priority in managing workload in the company.

Based on these theoretical studies, it can be indicated that there is a relationship between workload and employee performance. This is supported by the results of research conducted by Muhammad (2016), Sugiharjo (2018) who get the variable workload has a significant effect on employee performance. 
Based on the description above it can be concluded that workload has a positive and significant effect on performance, so that in managing the workload within the company must be done well and be a concern of management. In this regard, if the workload management has run well it is expected to improve employee performance in the company.

\section{Effect of Work Environment and Motivation on Workload (Hypothesis 6)}

$\mathrm{R}$ square value of motivation variable is 0.738 with $\mathrm{F}$ arithmetic of 59.277 , because the value of $\mathrm{F}$ arithmetic> $\mathrm{F}$ table (2.74), it is concluded that the work environment and motivation variables simultaneously have a significant effect on the workload variable with a large influence of simultans by $73.8 \%$, while the remaining $26.2 \%$ of PT. PLN (Persero) UP3 Kebon Jeruk is influenced by other factors outside the work environment and motivation.

Assumptions about the relationship between work environment variables, motivation and workload together on employee performance. Based on the results of the research that has been informed above, that each variable has a positive influence in influencing employee performance. For this reason, a temporary conclusion can be drawn that each variable, namely the work environment, motivation and workload on employee performance will be further investigated.

\section{Effect of Work Environment, Motivation and Workload on Performance (Hypothesis 7)}

$\mathrm{R}$ square value of the performance variable is 0.813 with a calculated $\mathrm{F}$ of 91.554 , because the value of $\mathrm{F}$ arithmetic $>\mathrm{F}$ table then concluded that the work environment, motivation and workload variables simultaneously have a significant effect on performance variables with a simultaneous influence of $81.3 \%$, this shows that $81.3 \%$ of the variance in the performance of employees of PT. PLN (Persero) UP3 Kebon Jeruk is influenced by the work environment, motivation and workload, while the remaining $18.7 \%$ of the performance of DG SDPPI employees is influenced by factors outside the work environment, motivation and workload.

Assumptions are interrelationships between work environment variables, motivation and workload together on performance. Based on the results of the research that has been stated above that each variable has a positive influence in influencing performance. For this reason, a temporary conclusion can be drawn that each variable, namely the work environment, motivation and workload together, has a positive effect on the performance to be further investigated.

\section{Workload Mediates Work Environment and Motivation for Performance (Hypothesis} 8)

The path coefficient value of the direct influence of the work environment on performance 0.076> the value of the path coefficient of the indirect effect of the work environment on performance is 0.136 then the work environment on performance mediated by workload variables and the value of the path coefficient of the direct influence of motivation on performance $0.249>$ direct compensation for performance is 0.264 then motivation for performance mediated by workload variables.

\section{CONCLUSION AND SUGGESTION Conclusion}

Based on the results of the research and discussion in the previous chapters, several conclusions can be made as follows: 
1. The work environment has a significant positive effect on workload, with the most nonphysical environmental dimensions being influential.

2. Motivation has a significant positive effect on workload, with the most influential hygiene dimension.

3. The work environment has a significant positive effect on performance, with the physical environment being the most influential.

4. Motivation has a significant positive effect on performance, with the most influential hygiene dimension.

5. Workload as a mediator in this study has a significant effect on performance.

6. Work environment and motivation together - a significant positive effect on workload.

7. The work environment and motivation and workload simultaneously have a positive and significant effect on performance.

8. Workload mediate the work environment and motivation for performance.

\section{Suggestions}

Based on the results of the analysis of the discussion and some conclusions above, the suggestions that can be given to complete the results of this study are as follows:

\section{For Agencies}

a. The results of correlation analysis between dimensions indicate that the Non-Physical Environment is quite significantly influencing the workload, namely smooth communication. In the sense that in the delivery of opinions and both the leadership of subordinates and subordinates to superiors must pay attention to communication. Communication aims to strengthen relations, both superiors with subordinates, subordinates with superiors or with peers to make it easier to carry out a plan, mission or to solve a problem.

b. Correlation analysis results between dimensions show that hygiene significantly influences workload, namely policy and administration. With the level of conformity felt by employees of all policies and regulations that apply in the company.

c. The results of correlation analysis between dimensions show that workload is quite significant in influencing performance, namely frustration. There are still a number of unproductive employees who cause uneven workloads or workloads that are charged by productive employees.

\section{For Further Researchers}

The expectation of the authors is that further research can explore more closely the variables that affect performance. The significant effect of workload as a mediator on the performance found in this study opens up the possibility of other effects of workload on other variables.

\section{REFERENCE}

Adityawarman, Yudha; Bunasor Sanim, and Bonar M Sinaga. (2015). Pengaruh Beban Kerja terhadap Kinerja Karyawan PT. Bank Rakyat Indonesia (persero) Tbk Cabang Krekot. Jurnal Manajemen dan Organisasi. Vol VI. No 1.

Armstrong, Michael and Stephen Taylor. (2014). Armstrong's Handbook of Human Resource Management Practice. $13^{\text {th }}$ Edition. Kogan Page. Hong Kong.

Luthans Fred. (2011). Organizational Behavior An Evidence-Based Approach. $12^{\text {th }}$ Edition. McGraw-Hill Companies. New York. 
Mangkunegara. (2017). Manajemen Sumber Daya Manusia Perusahaan. PT. Remaja Rosdakarya. Bandung.

Pranaputra, Randy Dwi and M. Havidz Aima (2019). The Effect of Workload and Compensation on Motivation and the Implication on Employee Performance of Directorate General of Postal Devices and Resource and Informatics Ministry of Communication and Informatics Republic of Indonesia. IJISRT. Volume 4, Issue 2.

Priyono and Idrus MS. (2014). Penelitian Kualitatif di Manajemen dan Bisnis. Pertama. Zifatama Publisher. Sidoarjo.

Robbins, Stephen P and Timothy A. Judge. (2013). Organizational Behavior. $15^{\text {th }}$ Edition Pearson Education, United States of America.

Samosri, Dialson Paulus; M. Havidz Aima; and Dr. Markum. MPd (2019). The Effect of Work Spirit and Competence on Work Motivation and its Implementation on Employee Productivity of Factory PT. Sinar Metrindo Perkasa. IJISRT. Volume 4, Issue 5.

Sedarmayanti. (2011). Manajemen Sumber Daya Manusia, Reformasi Birokrasi dan Manajemen Pegawai Negeri Sipil. Bandung : PT Refika Adiatama.

Siswanto, Siswanto; Achmad Sani Supriyanto, Ulfatun Ni'mah, Nur Asnawi, and Ismail Suardi Wekke. (2019). Does a workload influence the performance of bank employees. Management Science Letters 9. hal. 639-650. Canada.

Sri Rahayu Muhammad; Adolfina, and Genita Lumintang. (2016). Pengaruh Lingkungan Kerja, Kompensasi dan Beban Kerja Terhadap Kinerja Karyawan pada Dinas Pendapatan Daerah Kota Manado. Jurnal EMBA, Vol. 4, No. 1, Hal 045-055.

Sugiharjo, R. Joko and Friska Aldata. (2018). Pengaruh Beban Kerja dan Motivasi Kerja terhadap Kinerja Karyawan BPJS Ketenagakerjaan Cabang Salemba. Jurnal Ilmiah Manajemen Bisnis. Vol. 4, No. 1, hal 128-137.

Sugiyono. (2018). Metode Penelitian Pendidikan: Pendekatan Kuantitatif. Kualitatif. dan $R \& D$. Alfabeta. Bandung.

Suhaya1, and Jarnawi Afgani Dahlan. (2018). Is the Employee Performance Influenced by Organizational Culture, Work Environment, Work Motivation, and Job Satisfaction. International Journal of Science and Research (IJSR). Volume 7 Issue 12.

Syamsu, Nadya Nandavati; Mochamad Soelton, Andesna Nanda, Ratyuhono Linggarnusantra Putra, and Putri Pebriani,(2019). Bagaimanakah Konflik Peran dan Beban Kerja Mempengaruhi Kinerja Karyawan dengan Burnout sebagai Variabel Intervening. Jurnal Ilmiah Manajemen Bisnis. Vol. 5, No. 1.

Tarwaka. (2011). Ergonomi Industri : Dasar-Dasar Pngetahuan Ergonomi dan Aplikasi di Tempat Kerja. Harapan Press. Surakarta. 